\title{
A place to sleep at the start...
}

\section{Tim Luckburst and Laura Garcia}

\author{
Bed, breakfast and excellent advice: bow a new scheme can \\ belp impoverished students take advantage of internships
}

To clinch that first break in national or international news, many young journalists must prove themselves to a potential employer by working as interns in the capital. The cost barrier is colossal. Many have substantial student debts. Others rely on gruelling part-time jobs to pay their bills. The price of deposit and rent with no guarantee of a professional salary at the end is beyond them.

That is why the launch of PressPad, the BBC journalist Olivia Crellin's ambitious project to pair aspiring journalists with news professionals who can offer free accommodation and mentoring in London, is so thrilling.

At the University of Kent's Centre for Journalism, we know too well the misery of ambitions stymied and dreams shattered. Many of our students are from homes in which the bank of mum and dad is gravely undercapitalised or does not work at all. These young people often work exceptionally hard and achieve tremendous results, but increasingly their further progress is threatened by the economic difficulty of finding a place to live where the work is.

A few employers offer generous help. The Daily Mail, Sky News and the Worshipful Company of Stationers and Newspaper Makers, sponsor students at Kent. But too few employers match their ambition to diversify recruitment with the hard cash required to make it happen. Now, PressPad offers a realistic solution for those with bags of talent but no sponsor.

Crellin is clear about its purpose: "We want to reduce that financial barrier. If you can't afford to show up to work, you don't have much of a 
chance." And it isn't just the talented young people who are disadvantaged: if employers really want to create newsrooms that reflect the diversity of the society they cover; if they want to remain informed, relevant and responsive, then they urgently need to eradicate the barriers to effective social inclusion.

Granted, there is a solid objection to unpaid internships. They are intrinsically divisive and should not exist. Crellin acknowledges this: "A lot of people have commented that we might be enabling unpaid internships, but this is not a scheme to encourage that. It is a stopgap until the campaigns to end unpaid internships are successful." To us, this sounds like good sense: only an ideological zealot makes perfection the enemy of progress - and progress certainly needs a little help. Many top employers are less well-funded than at any time in living memory. If they did not abolish unpaid internships when they could afford to take risks, the likelihood of them doing so now is vanishingly small. So PressPad is a practical solution as well as an idealistic one. It can make real differences by permitting young people with limited funds to compete with their peers from more affluent backgrounds. It does not aspire to unjust outcomes or propose an obnoxious exercise in social engineering. It intends simply to promote fair competition; to let poor students compete with Etonians on the basis of ability, not parental income.

Will it work? We believe the principle is already proven. We have seen superb students prove their expertise in busy national newsrooms because Sky News or Associated Newspapers have funded accommodation and offered guidance. We have seen confidence surge in young people who had not previously experienced the buzz of a national title or network broadcaster. Last year, one of our undergraduates did so much to impress on an internship at Sky News that she has worked paid shifts there during her second year at university. Another student, on a fully-funded two-week internship at the Daily Mail, did enough to secure a full-time job as a reporter. From wondering whether they would ever be able to compete at the highest level, these young women acquired the confidence to be certain that they can.

And PressPad has made a tremendous start. Among the mentors who have volunteered accommodation is Catherine Philp, diplomatic editor of The Times. Her own career has taught her how much the accommodation and advice PressPad offers can be worth: "I've mostly worked abroad and I owe a great deal to people who opened their doors to me. I stayed with a friend in Indonesia for three months when I moved there from Cambodia and could not have got started without his help. I've never forgotten that and so have 
lent a spare bed or sofa in foreign parts to budding journalists before now. Now I'm back in London and actually have a spare room (though it's more a bed in the study), it seems absolutely the right way to help. Speaking to young would-be journalists is always interesting and I learn a lot from it too, including the fact I may have more to pass on than I thought.”

Another enthusiastic early adopter is investigative journalist Meirion Jones, a veteran of BBC flagship shows including the Today programme, Panorama and Nemsnight. Now investigations editor at the Bureau of Investigative Journalism, Jones explains: "Unless you are rich, or you live in London, working in the capital is unbelievably difficult. But 80 to 90 per cent of the top journalism jobs are in London. So if we are going to make journalism less white and less middle-class, it is crucial that we allow talented young people the chance to get the experience they need." Jones and his wife, television journalist Kate Middleton, have a spare bedroom and they are looking forward to mentoring interns too. "When I was young, I thought that older, more experienced journalists wouldn't want to know me," says Jones. "In fact, I find most older colleagues are keen to help. I hope the interns will find it really useful to come back after a day in a newsroom and talk to somebody who can offer practical guidance and advice rooted in real experience."

\section{Guidance and contracts thrown in}

When we spoke, Jones and Middleton were expecting the arrival of PressPad's very first beneficiary, Jabir Mustapha Sambo, a student from Robert Gordon University in Aberdeen who has secured a precious internship 550 miles south of the Granite City at the BBC in London. Other pairings in this inaugural phase of the project include Jem Bartholomew, a 22-year-old from Exeter. Next year he plans to complete a cherished internship at Vogue, courtesy of accommodation and mentoring from John Nugent, news editor of Empire magazine.

Bartholomew has already proved his ability by going from a low-income household to Oxford University. But he has no family savings to fall back on and, until PressPad came along, feared being frozen out of his internship by the unaffordability of London. He says: "It's encouraging to see celebrated journalists willing to lend a hand to those at the beginnings of their careers, especially at a time when ad-based business models are declining and money is tight." While he is delighted simply to have the 
chance to learn at Condé Nast's headquarters in the heart of Mayfair, Bartholomew applauds PressPad's wider ambitions too: "Unrepresentative journalism is bad journalism: if Britain's newsrooms don't reflect wider society, everyone suffers.”

Eighteen-year-old Annissa Warsame from Birmingham is a student of history and politics at the University of Exeter. She was honoured to be awarded the inaugural Bright Young Reporter internship with OpenDemocracy, the independent, non-profit platform that aims to challenge power and encourage debate. But Warsame's first reaction on learning that she had won the prestigious prize was that she couldn't afford to accept it. As a child, she received free school meals. And, although her family are fully behind her ambition to work in journalism, they cannot fund her food, travel or accommodation. Warsame says the PressPad scheme has made it possible: "With one less cost to worry about, I can engage with my internship wholly." She also hopes to learn from her host: "If I have a particularly interesting or confusing day at work, I'll ask my mentor questions to help me learn and improve any weaknesses."

Daniel Clark, 24, of Banbury in Oxfordshire, a student at the University of Cardiff, beat stiff competition to secure a Google Fellowship at the BBC News Lab in London, but he too was alarmed by the cost: "The fellowship is a massive opportunity, so I considered getting a short-term loan to cover a hostel room or bed and breakfast in London. When I found out about PressPad, I couldn't believe it. It is ideal." Clark's is an extended internship, so PressPad has lined up four journalists, each of whom will host him for two weeks. One host and mentor will be Aubrey Allegretti, digital political reporter at Sky News.

Philp, of The Times, has promised board, lodging and professional guidance to Julia Atherley, a student from Ripon in North Yorkshire whose internship is at The Sunday Times. Philp calls PressPad "a brilliantly simple idea that fulfils a very clear need". She understands that some young people who desperately want and deserve to be journalists lack the contacts to do so or have nowhere they can stay if they secure a valuable internship, the majority of which are in London. She is determined that bright students should not be prevented from taking up opportunities because they lack capital, financial or cultural.

We share her determination and we are certain that PressPad offers a pragmatic solution. Our certainty is reinforced by experience, some of it intensely personal. Laura Garcia Rodriguez Blancas, one of the authors of 
this article, came to the UK from Mexico to learn journalism as a postgraduate student in the Centre for Journalism. Her studies were funded by a competitive scholarship, but when it came to the internships and work experience that would kick-start her career in broadcast news, she relied on the kindness of strangers. She could not have done precious time at BBC Radio 4 or Channel 5 News without the generosity of journalists who gave her a precious bed - or sofa - to sleep on. 'I wouldn't have been able to do it otherwise. It wasn't just a place to sleep, I made new and important contacts by staying with other journalists, plus they understood my weird working hours," she explains. "Without them I would not have made the breakthrough into national and international news. It is that simple. PressPad is Airbnb for journalists, but with inspiring mentors thrown in."

And this is just the beginning. PressPad is in its launch phase and has ambitions to grow big enough to really challenge social exclusion. With that noble aspiration in mind, Crellin plans a formal launch event in September. She would love to find a sponsor who can make the party go with a swing.

Her simple but brilliant idea has already made possible internships that would not have happened without it. There will be teething problems, not least in the vetting of hosts and mentors to ensure all accommodation is secure and supportive. But the best way forward is simply to facilitate contact between aspiring journalists and seasoned professionals who offer help. The pioneers who have responded so generously to Crellin's initial appeal have proved that British journalists are kind enough and fair enough to support deserving cases. As journalists who now teach the journalists of the future, we know that there are many such cases and that a substantial number of the best among them are not wealthy. Truly, PressPad is an idea whose time has come

Tim Luckburst is bead of the Centre for Fournalism at the University of Kent. Laura Garcia Rodriguez Blancas is lecturer in television and multimedia journalism in the Centre. 